\title{
PENGARUH CITRA MEREK, HARGA DAN KUALITAS PRODUK TERHADAP KEPUTUSAN PEMBELIAN SEPATU SNEAKERS MEREK CONVERSE PADA MAHASISWA UNIVERSITAS KANJURUHAN MALANG
}

\author{
Hori Andayani \\ (Program Studi Manajemen, Fakultas Ekonomika dan Bisnis Universitas Kanjuruhan Malang) \\ e-mail: Horihandayani@gmail.com \\ Iva Nurdiana Nurfarida \\ Rusno \\ (Program Studi Manajemen, Fakultas Ekonomika dan Bisnis Universitas Kanjuruhan Malang)
}

\begin{abstract}
ABSTRAK : Penelitian ini bertujuan untuk mengetahui apakah citra merek, harga dan kualitas produk berpengaruh terhadap keputusan pembelian sepatu sneakers merek converse pada mahasiswa Universitas Kanjuruhan Malang. penelitian menggunakan penelitian kuantitatif, populasi nya adalah Mahasiswa Universitas Kanjuruhan Malang, metode pengambilan sampel menggunakan accidental sampling. Pengambilan Data diambil menggunakan kuesioner yang diukur menggunakan skala likert, analisisnya menggunakan regresi liner berganda. Hasil ini menunjukan variabel citra merek, harga dan kualitas produk mempengaruhi secara simultan terhadap keputusan pembelian, karena dilihat dari hasil uji F. citra merek mempengaruhi secara parsial keputusan pembelian, karena hasil uji t. sedangkan harga dan kualitas produk juga memepnegaruhi keputusan pembelian dilihat dari hasil uji parsial.
\end{abstract}

\section{PENDAHULUAN}

Seiring brekembangnya dunia bisnis, sepatu bukan hanya lagi sebagai salah satu pemenuhan keinginan melainkan juga sebagai salah satu unsur kebutuhan didalam bidang fashion pada mahasiswa, hal ini juga membuat para produsen melihat keinginan dan kebutuhan dari konsumen dijadikan sebagai salah satu peluang untuk menciptakan sebuah produk.

Sepatu merupakan salah satu alat pengalas kaki yang befungsi untuk melindungi kaki. merek yang diciptakan oleh perusahaan harus memiliki unsur yang mudah diingat oleh konsumen agar bisa memberikan keyakinan positif. Selain itu Harga juga menentukan keberhasilan sebuah bisnis karena dengan harga yang begitu menyesuiakan dengan kemampuan konsumen dan kualitas produk yang akan diterima maka konsumen akan tertarik pada produk tersebut. Harga sering kali digunakan konsumen untuk menentukan pilihan.

Harga sangat penting didalam sebuah keputusan pembelian pada konsumen karena jika kualitas produk yang akan ditawarkan perusahaan sesuai konsumen akan melakukan pembelian ulang atas produk tersebut.

\section{TINJAUAN PUSTAKA}

Kotler \& Amstrong (2016) bagian dari perilaku konsumen yang berkaitan dengan bagaimana individu, membeli, menggunakan barang atau jasa yang memuaskan keinginana nya adalah keputusan pembelian.

Menurut Ketrajaya (2010) citra merek adalah bagian dari value indicator karena dengan brand yang digunakan bisa menciptakan dan menambah value pada produk, perusahaan dan bahkan Negara. Kotler dan amstrong (2010) yang dibebankan oleh konsumen atas barang yang berupa sejumlah uang adalah harga.

Menurut alferd (2013) kemampuan yang dimiliki suatu produk yang berfungsi untuk daya tahan, keandalan, ketepatan, kemudahaan dan perbaikan yaitu kualitas produk. 
Pengaruh Citra Merek, Harga Dan Kualitas Produk Terhadap Keputusan Pembelian Sepatu Sneakers Merek Converse Pada Mahasiswa Universitas Kanjuruhan Malang

\section{KERANGKA KONSEPTUAL}

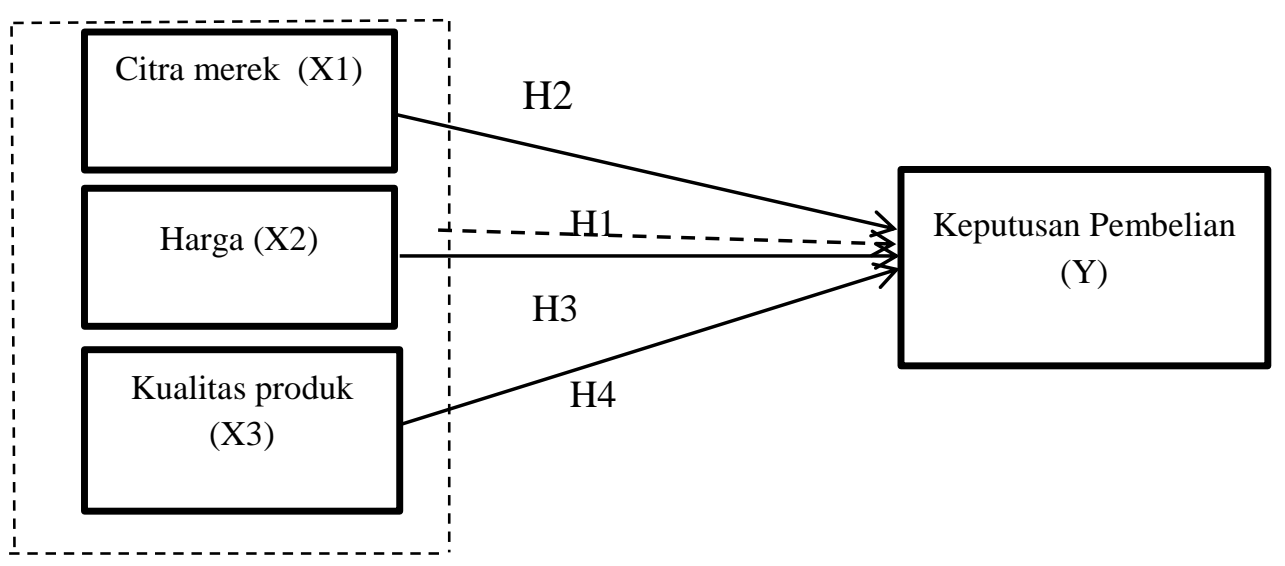

Sumber : data diolah 2020

Keterangan:

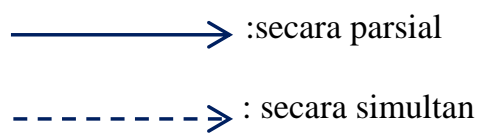

\section{HIPOTESIS}

1. Citra merek, Harga dan Kualitas produk mempengaruhi keputusan pembelian sepatu converse Mahasiswa Universitas Kajuruhan Malang.

2. Citra merek mempengaruhi keputusan pembelian sepatu converse Mahasiswa Universitas Kanjuruhan Malang.

3. Harga mempengaruhi keputusan pembelian sepatu converse Mahasiswa Universitas Kanjuruhan Malang.

4. Kualitas produk mempengaruhi keputusan pembelian converse Mahasiswa Universitas Kanjuruhan Malang.

\section{METODE PENELITIAN}

Penelitian ini menggunakan teknik accidental sampling. Menurut Ferdinand (2011) bahwa ukuran sampel 100200 berpedoman 5-10, penelitian ini jumlah sampelnya adalah $6 \times 17=102$ responden. menggunakan analisis regresi linier berganda, uji asumsi klasik, uji hipotesis terdiri dari uji f, uji t dan uji determinasi.

\section{HASIL PENELITIAN}

1. Uji Asumsi Klasik

a. Uji normalitas dengan garis putus-putus yang menyebar mengikuti garis diagonal hal ini berati data bersitribusi normal.

b. Uji Hekteroskedatitas titik menyebar dibawah 0 sumbu $Y$ artinya bahwa data tidak terjadi heteroskedatitas.

c. Uji Multikolinieritas variabel bebas memiliki nilai tolerance > 0,1 yaitu 0,936, 0,37, 0,997 nilai VIF < 10 yaitu 1,068, 1,067 dan 1,003 jadi tidak terjadi multikolinieritas.

2. Uji Hipotesis
a. Uji f
jika nilai sig f $0,014<0,05$ menunjukan bahwa citra merek, harga dan kualitas produk memiliki pengaruh secara simultan terhadap keputusan pembelian.
b. Uji t 
Pengaruh Citra Merek, Harga Dan Kualitas Produk Terhadap Keputusan Pembelian Sepatu Sneakers Merek

Converse Pada Mahasiswa Universitas Kanjuruhan Malang

Citra merek menunjukan nilai t $0,006<0,05$ berarti ada pengaruh sigifikan dari citra merek sedangkan harga menunjukan nilai sig 0,041 $<0,05$ berarti ada pengaruh signifikan dari harga terhadap keputusan

pembelian, kualitas produk menunjukan nilai t 0,018<0,05 berarti ada pengaruh signifikan dari kualitas produk terhadap keputusan pembelian.

3. Analisis Regresi Linier Berganda

a. Nilia kostanta 38,425 angka tersebut menunjukan tingkat keputusan pembelian yang diperoleh.

b. Citra merek mempunyai nilai 0,670 artinya kenaikan X1 sebanyak 1 akan berpengaruh sebesar 0,670 terhadap keputusan pembelian (Y) oleh karena itu semakin bagus citra merek.

c. Harga mempunyai nilai -0,335 dengan nilai negatif artinya bahwa keputusan pembelian akan menurun sebesar -0,335 oleh karena itu semakin tinggi harga.

d. Kualitas produk mempunyai nilai -0,132 dengan nilai negatif artinya setiap peningkatan kualitas produk 1 kali keputusan pembelian akan menurun sebesar -0,132 oleh karena itu jika kualitas produk rendah.

4. Uji determinasi

Diketahui besarnya nilai $\mathrm{R}$ square 0,480 atau $48 \%$ berarti kemampuan variabel bebas mempengaruhi secara bersama.

\section{PEMBAHASAN}

Pengaruh citra merek, harga dan kualitas produk terhadap keputusan pembelian

Berdasarkan hasil analisis pengujian stastistik dalam penenlitian menunjukan citra merek, harga dan kualitas mempengaruhi secara bersama-sama terhadap keputusan pembelian dengan menujukan bawah signifikan pada uji f lebih besar dari kesalahan. Hasil ini membuktikan bahwa hipotesis yang dinyatakan diterima.

\section{Pengaruh citra merek terhadap keputusan pembelian}

Hasil analisis sebelumnya telah diketahui hubungan antara citra merek terhadap keputusan pembelian memiliki pengaruh yang positif. dapat disimpukan bahwa citra merek sudah tertanam dibenak mahasiswa Universitas Kanjuruhan Malang karena dapat dilihat dari faktor yang mempengaruhi dan bisa diterima oleh mahasiswa dan konsumen lainya.

Penjelasan diatas memiliki arti ketika perusahaan ingin meningkatkan pembelian pada produk, hal yang perlu dilakukan yaitu meningkatkan citra perusahan agar lebih baik. Semakin Tingginya citra perusahaan yang di dapatkan para konsumen, maka akan berdampak pada keputusan pembelian konsumen yang semakin naik pula. Oleh karena citra perusahaan merupakan hal yang paling utama yang mejadi keputusan konsumen.

\section{Pengaruh harga terhadap keptusan pembelian}

Hasil statistik menunjukan artinya jika konsumen melakukan pembelian dan juga memiliki hubungan yang negatif. Dari hasil analisis tersebut menunjukan bahwa harga juga merupakan hal yang paling penting dalam penilai konsumen untuk memutuskan pembelian suatu barang.

Penjelasan diatas memiliki arti jika perusahaan ingin meningkatkan keputusan pembelian suatu barang perusahaan juga akan memberikan harga suatu barang sesuai dengan kualitas dan citra merek yang ada dalam suatu perusahaan, didalam hasil analisis diatas menunjukan bahwa harga memiliki nilai yang negatif.

\section{Pengaruh kualitas poduk terhadap keputusan pembelian}

Hasil analisis menggunakan statistik menunjukan kualitas produk berpengaruhi secara parsial yang artinya bahwa hal itu yang sangat penting diperhatikan sebelum dalam melakukan keputusan pembelian. hasil analisis diatas menunjukan bahwa kualitas produk memiliki pengaruh yang negatif. Yang memiliki arti bahwa jika kualitas suatu produk turun maka minat konsumen akan suatu barang akan turun.

\section{KESIMPULAN}

Berdasarkan hasil penelitian diatas tentang Pengaruh Citra merek, Harga dan Kualitas produk terhadap keputusan pembelian sepatu snekaers merek converse pada Mahasiswa Universitas Kanjuruhan Malang, dapat kita tarik kesimpulan sebagai berikut: 
Pengaruh Citra Merek, Harga Dan Kualitas Produk Terhadap Keputusan Pembelian Sepatu Sneakers Merek Converse Pada Mahasiswa Universitas Kanjuruhan Malang

1. Berdasarkan analisis yang dilakukan secara simultan menunjukan hasil yang positif.

2. Berdasarkan analisis secara parsial, hasil penelitian membuktikan bahwa variabel independen mempengaruhi variabel dependen yaitu keputusan pembelian yang bernilai positif. Sedangkan secara parsial memiliki pengaruhi yang negatif antara harga terhadap keputusan pembelian.

\section{SARAN}

Berdasarkan hasil jawaban responden pada variabel keputusan pembelian yang ada pada mahasiswa Universitas Kanjuruhan Malang, jadi terdapat saran dalam penelitian ini:

1. Sepatu sneakers merek converse harus mampu menunjukan memberikan keunggulan yang lebih baik lagi dari sepatu merek lain.

2. Sepatu sneakers merek converse harus mampu mampu memberikan harga yang sesuai dengan kemampuan konsumen sehingga konsumen tetap tertarik dengan loyal terhadap produk sepatu sneakers merek converse.

3. Untuk penelitian selanjutnya agar lebih memperhatikan variabel-variabel terbaru yang bisa memepengaruhi seperti kualitas pelayanan dan promosi.

\section{DAFTAR PUSTAKA}

Liga, Mananeke dan Janteje 2014. Minahasa sonder Center di Bentenan keputusan konsumen yang bepengaruh terhadap kualitas produk, harga dan promosi.

Kertajaya. 2010. Operation Jakarta Branda : Esensi Group Erlangga.

Kotler \& Amstrong. 2010: Principle Of Marketing, 15th edition. New Jersey: Pearson Pretice Hall.

Mohamad Rizan 2017. Indonesia PT Schneider produt transformer decision purchase on risk perceiver and $w$ product, price, brand image of the influence. 